\title{
T. МЕЙДЛА
}

\section{НОВЫЕ ОСТРАКОДЫ ИЗ ОРДОВИКА ПРИБАЛТИКИ}

Ниже приводится описание некоторых новых видов остракод, установленных в отложениях раквереского и набалаского горизонтов Северной Эстонии. По Tetrada neckajae sp. п. и Tetrada variabilis sp. n. имеются еще материалы из Восточной Латвии, где данные виды распространены в низах набалаского горизонта. Распространение видов указано в таблице.

Стратиграфическое распространение описанных видов остракод

\begin{tabular}{|c|c|c|c|c|c|}
\hline \multirow[b]{2}{*}{ Виды } & \multicolumn{2}{|c|}{$\begin{array}{l}\text { Раквереский } \\
\text { горизонт (E) }\end{array}$} & \multicolumn{3}{|c|}{ Набалаский горизонт $\left(\mathrm{F}_{1} \mathrm{a}\right)$} \\
\hline & $\begin{array}{l}\text { пийлсе- } \\
\text { ская } \\
\text { пачка } \\
\text { (E'P) }\end{array}$ & $\begin{array}{c}\text { тудуская } \\
\text { пачка } \\
\text { (E'T) }\end{array}$ & $\begin{array}{c}\text { тудуская } \\
\text { пачка } \\
\left.\text { (F }{ }_{\text {IaT }}\right)\end{array}$ & $\begin{array}{c}\text { паэкна- } \\
\text { ская } \\
\text { пачка } \\
\left(\mathrm{F}_{\mathrm{I}} \mathrm{aP}\right)\end{array}$ & $\begin{array}{l}\text { саунья- } \\
\text { ская } \\
\text { пачка } \\
\left(\mathrm{F}_{\mathrm{I}} \mathrm{aS}\right)\end{array}$ \\
\hline $\begin{array}{l}\text { Seviculina reticulata } \\
\text { gen. } \mathrm{n} . \mathrm{sp} . \mathrm{n} . \\
\text { Tetrada neckajae sp. } \mathrm{n} . \\
\text { Tetrada variabilis } \mathrm{sp} . \mathrm{n} . \\
\text { Pyxion rakverensis } \mathrm{sp} . \mathrm{n} . \\
\text { Primitiella? insolens } \mathrm{sp} . \mathrm{n} \text {. } \\
\text { Hemiaechminoides minuscu- } \\
\text { lus } \mathrm{sp} . \mathrm{n} .\end{array}$ & $\begin{array}{l}+ \\
+ \\
+ \\
+ \\
+\end{array}$ & $\begin{array}{l}+ \\
+ \\
+ \\
+\end{array}$ & + & $\begin{array}{l}+ \\
+ \\
+ \\
+ \\
+\end{array}$ & + \\
\hline
\end{tabular}

Коллекция, являющаяся основой данной работы, происходит из скважин Винни, Ваянгу, Килтси, Ярва-Мадизе, Моэ и Берзини (Восточная Латвия), а также с обнажений Пийлсе, Рягавере, Моонакюла и Паэкна. Материалы собраны Л. Сарвом (ИГ АН ЭССР), А. Хаасом и Х. Перенс (Управление геологии ӘССР), которым автор выражает свою признательность.

Фотографирование раковин на сканирующем электронном микроскопе проведено Е. Климовым (ИГ АН ЭССР). Фотографирование обычным способом выполнено автором.

\section{Описание фауны}

Семейство Tetradellidae Swartz, 1936

Подсемейство Sigmoopsinae Henningsmoen, 1953

Род Seviculina gen. $\mathrm{n}$.

Название рода. Комбинация от названий близкого рода Severobolbina и типового вида нового рода reticulata (окончание женского рода -ina). 
Типово й вид. Seviculina reticulata sp. п. Эстонская CCP, раквереский и набалаский горизонты.

Ди агноз. Слабо преплетные однобороздчатые остракоды; борозда короткая, дугообразная, бугор перед ней слабый или не развит. У самцов велюм в виде более или менее ясно выраженного невысокого гребня, в заднебрюшной части раковины удаляется от свободного края и может кончаться тупым шипиком. У самок велюм и гистиум отчетливые, соединены в переднебрюшной части створки. У левой створки отмечается по разной мере развитая маргинальная скульптура. Боковая поверхность сетчатая.

В и довой состав. Кроме типового вида представлен Haploprimitia oanduensis Sarv, 1956.

С р а внени е. Seviculina gen. п. близкая к Severobolbina Schallreuter, 1974 , напоминает ее по характеру диморфизма и расчленению створок (однобороздчатые створки, слаборазвитый велюм у самцов, наличие велюма и гистиума у самок). В отличие от Severobolbina у самок Seviculina велюм развит более слабо и гистиум находится ближе к свободному краю. Самцы Seviculina отличаются удаленным от свободного края велюмом, приподнятым в заднебрюшной части створки на боковую поверхность.

От остальных однобороздчатых Tetradellidae Seviculina отличается характером диморфизма.

Р аспространение. Средний и верхний ордовик, Эстонская ССР.

Seviculina reticulata gen. $\mathrm{n}$. sp. $\mathrm{n}$.

Табл. I, фиг. $1-10$

Голотип. Раковина Os 3033 в ИГ АН ЭССР; обн. Рягавере, Е'Р. Ди агноз. Seviculina с вытянутой раковиной. Велюм у самцов и гистиум у самок дугообразные, приподнятые в задней половине створки.

Р а з меры голотипа, мм: Д $-0,97 ; \mathrm{B}-0,45$ (соотношение размеров см. рис. 1).

О п и с а н ие. Раковина маленькая, преплетная. Спинной край длинный, спина гипоклинная. Передний конец широко закруглен, задний скошен у брюшного края. Брюшной край плоскодугообразный, наклонен к переднему концу. Наибольшая длина раковины выше середины.

Боковая поверхность расчленена короткой, доходящей примерно до середины створки бороздой, помещающейся значительно ближе к переднему концу раковины. Борозда более или менее дугообразна, в нижней части глубокая, выше нечетко ограничена, расширяющаяся. Бугор перед ней едва заметен, лишь со стороны борозды четко ограничен.

У самцов велюм в виде невысокого гребня развит от переднего края до заднебрюшной части створки, где он значительно удален от свободного края и кончается тупым шипиком. Между велюмом и свободным краем на переднем и переднебрюшном краях образуется широкая, слабовогнутая полость.

У самок велюм начинается от свободного края створки немного выше середины переднего конца и протягивается до средней части брюшного края. В переднебрюшной части створки от нее разъединяется гистиум и, постепенно удаляясь от свободного края, протягивается до заднебрюшной части створки. Велюм под гистиумом выражается относительно слабо. По вогнутым полостям велярного и гистиального долонов протягиваются тонкие продольные гребни. 
Левые створки имеют на брюшном и заднебрюшном краях маргинальную скульптуру в виде лучистого ребра.

Поверхность створок мелкосетчатая.

Из ме н ч и вость. Основные признаки характеризуются постоянством. Личинки отличаются от взрослых самцов меньшими размерами.

С р а внение. Новый вид отличается от S. oanduensis (Sarv, 1956) более вытянутой раковиной, удаленным от свободного края велюмом у самцов .и шипиком на ее конце. У самок $S$. oanduensis гистиум короткий и значительно приподнят, почти параллельный свободному краю, напоминая диморфные структуры Severobolbina. У S. reticulata гистиум длиннее, дугообразный.

Р а сп р остр а нен и е. Экземпляры данного вида встречаются довольно редко в отложениях раквереского горизонта (E) и в набаласком горизонте $\left(\mathrm{F}_{\mathrm{I}} \mathrm{a}\right)$ Северной Эстонии.

Местон ахождение и м а тери ал. Пийлсе, E'P - 4 экз.; Рягавере, 'Е'Р - 4 экз.; скв. Винни, Е'Р, гл. 34,5-36,2 м - 3 экз.; Е'Т, гл. 31,65 м - 2 экз.; $\mathrm{F}_{\mathrm{I}} \mathrm{P}$, гл. 25,5 м - 1 экз.; скв. Моэ, $\mathrm{F}_{\mathrm{I}} \mathrm{aS}$, гл. 26,1 м -2 экз.

Семейство Ctenonotellidae Schmidt, 1941

Подсемейство Ctenonotellinae Schmidt, 1941

Род Tetrada Neckaja, 1958

Tetrada neckajae $\mathrm{sp} . \mathrm{n}$.

Табл. III, фиг. $1-6$

Голотип. Правая створка Os 3037 в ИГ АН ЭССР; скв. Винни, гл. 15,5 м, набалаский горизонт, паэкнаская пачка.

Ди агноз. Раковина маленькая, амплетная. Четвертая лопасть связана с боковой лопастью узким гребнем. Передние борозды короткие,

\section{ТАБЛИЦА I}

1-10. Seviculina reticulata gen. n. sp. n. $1-4-$ голотип, раковвнна текноморфа Os 3033 , вид с правой и левой стороны, со спинного и брюшного краев, скв. Винни, гл. 36,2 м. E'P; 5-6 - раковина текноморфа Os 3032 со стороны левой створки и переднебрюшная часть раковины, Рягавере, E'P; 7 - раковина личинки Os 3031 с левой стороны, Пийлсе, E'P; 8-9 - раковина гетероморфа Os 3029 с правой стороны и брюшного края, скв. Винни, гл, 38,5 м, Е'Р; 10 - левая створка гетероморфа Os 3045. брюшная часть, Пийлсе, E'P

11-12. Seviculina oanduensis (Sarv, 1956), раковина гетероморфа Os 3073 co cтороны брюшной части левой створки и брюшного края. Тырремяги, DIII.

Изображения 5-6, 10-12 получены на сканирующем электронном микроскопе (СЭМ). Увеличения: $1-4,7-9-\times 48 ; 5-\times 78 ; 6-\times 234 ; 10-\times 59 ; 11-$ $\times 70 ; 12-\times 62$.

\section{ТАБЛИЦА II}

1-3. Seviculina oanduensis (Sarv, 1956). 1-2 - раковина текноморфа Os 3070, внд с левой стороны и участок боковой поверхности со серединной бороздой, Тырремяги, DIII; 3 - раковина текноморфа Os 3072 со стороны брюшного края, Тырремягн,

4-8. Hemiaechminoides minusculus sp. n. 4-7 - голотип, раковина Os 3001 со стороны левой и правой створок. спинного края и переднего конца, скв. Ваянгу, гл. 125.5 м, Е; 8 - раковина Os 3048 со стороны левой створки, скв. Ваянгу, гл. 125,5 м. Е.

Изображения $1-3.8$ получены на СЭМ. Увеличения: $1-\times 90 ; 2-\times 230$; $3-\times 78 ; 4-7-\times 72 ; 8-\times 173$. 
ТАБЛИЦА I
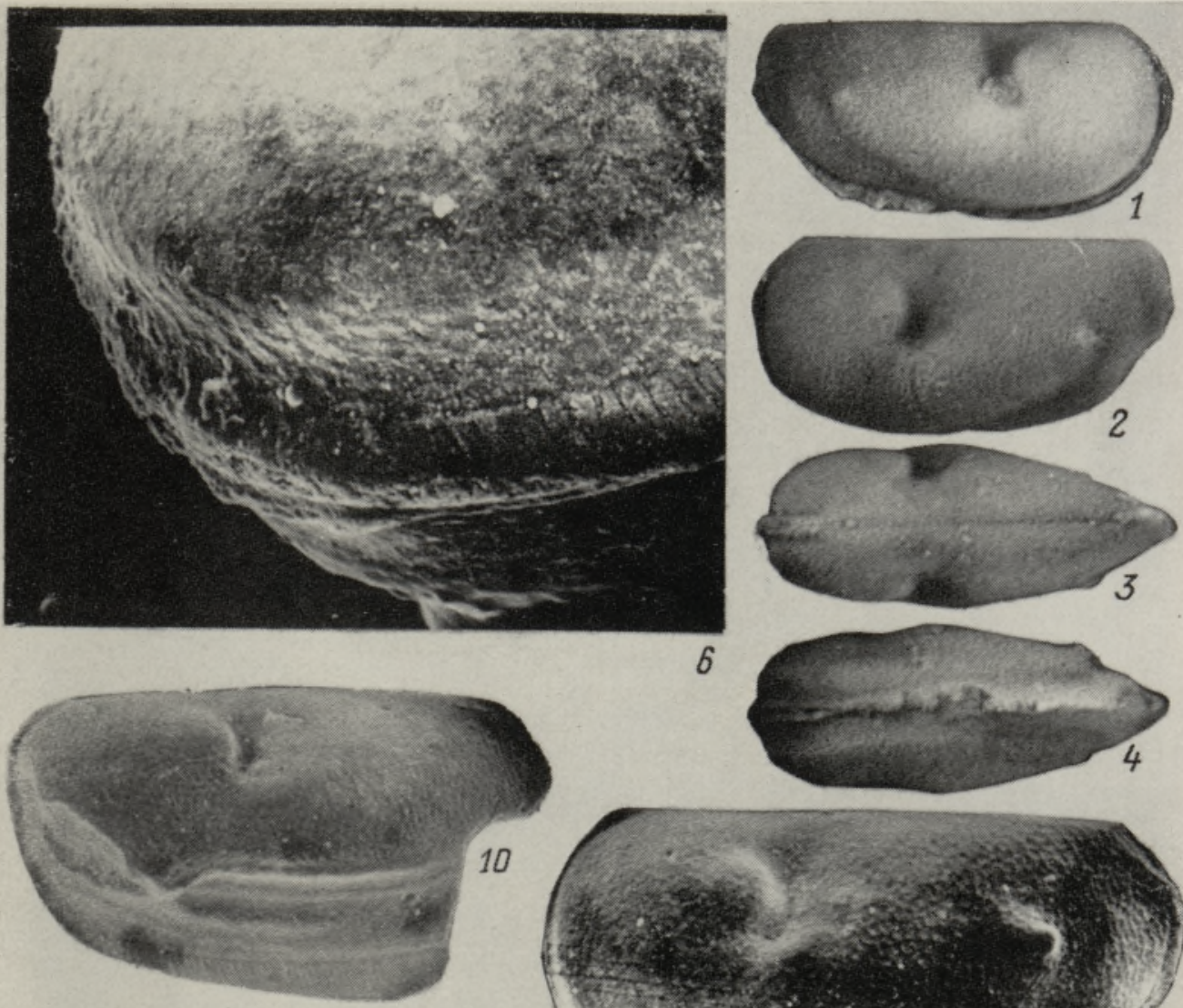

6
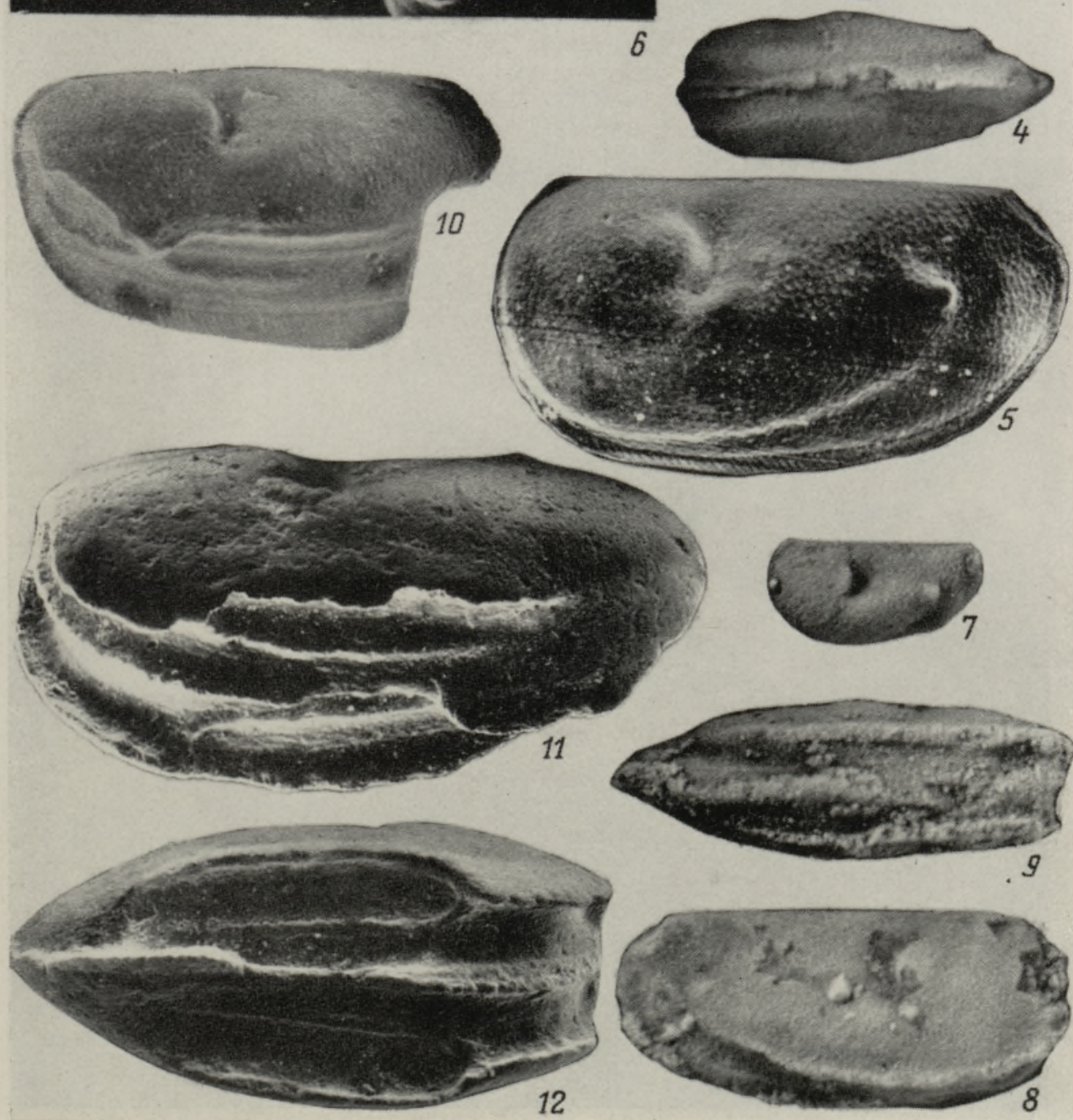
ТАБЛИЦА II
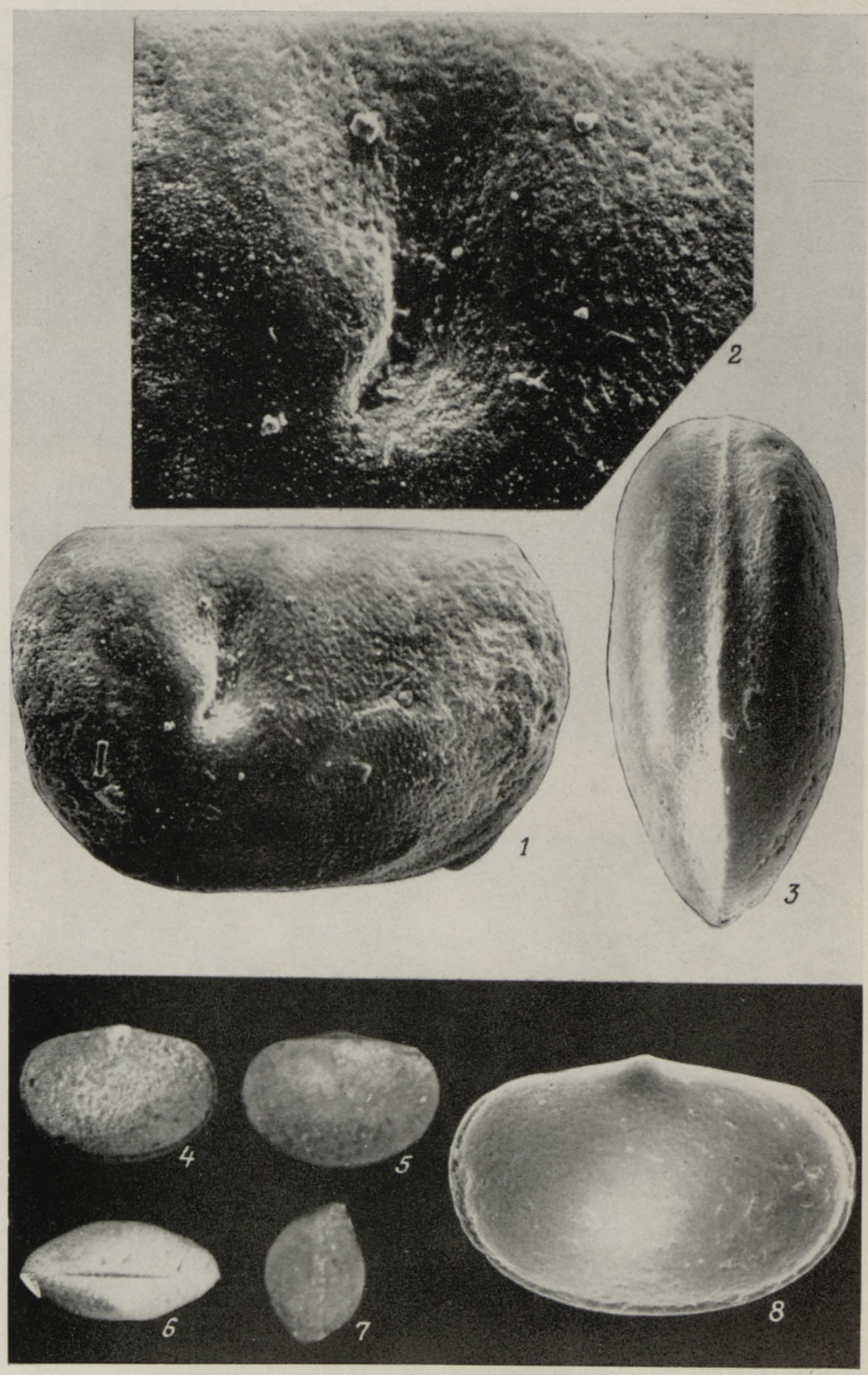


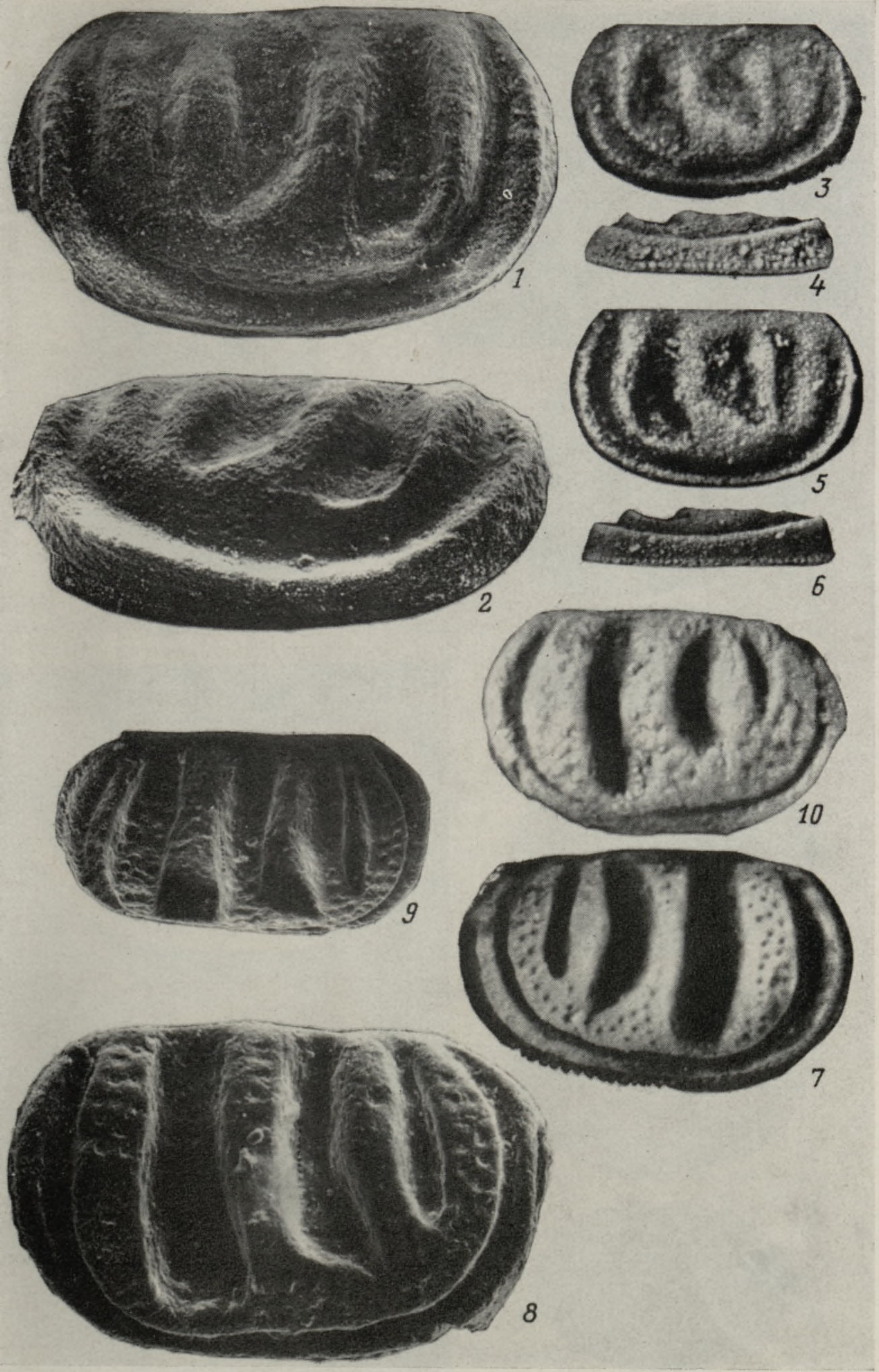



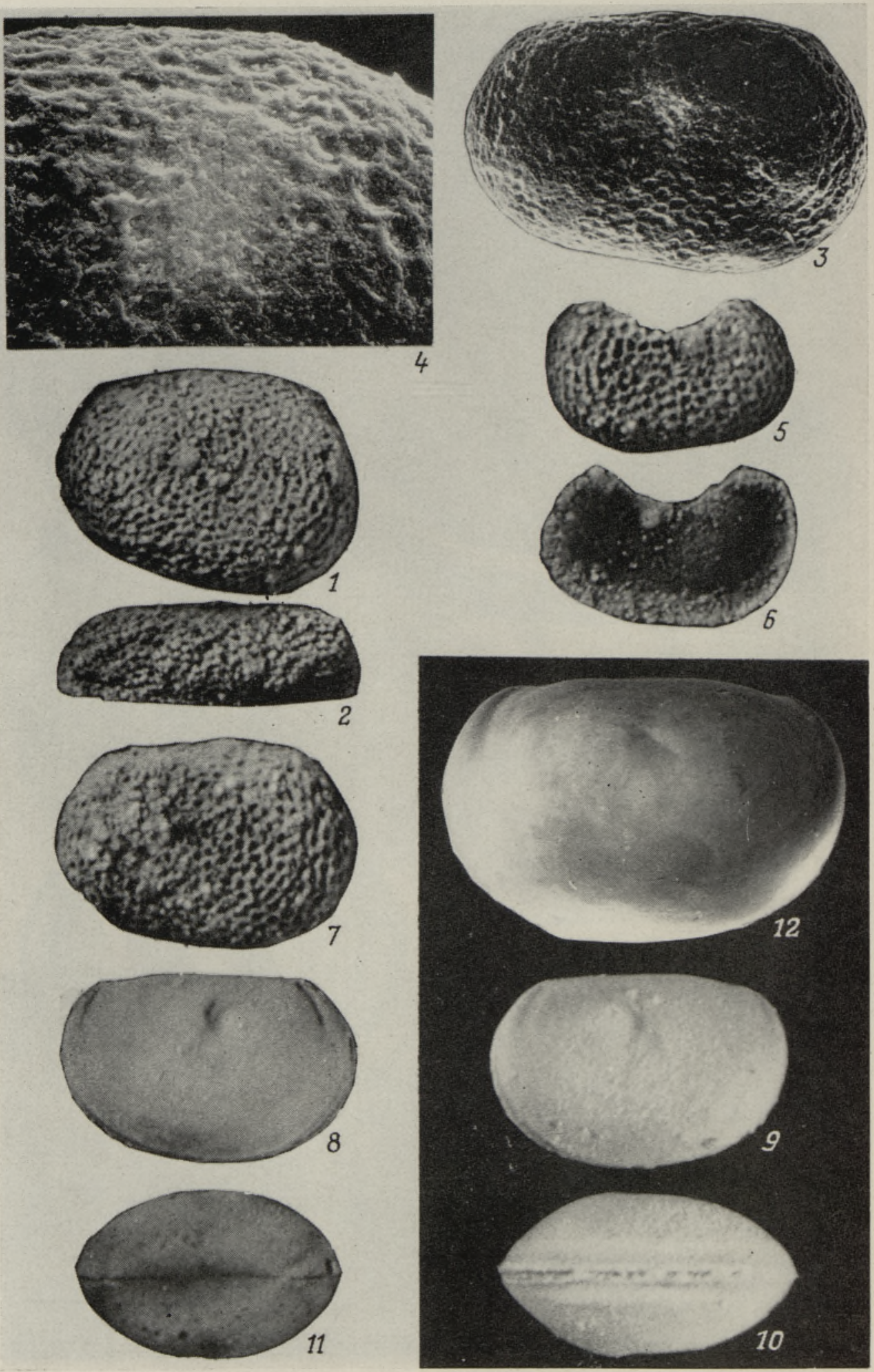
вторая значительно шире передней, угловатая. Борозда между лопастью и велюмом широкая, нечетко ограниченная. Поверхность гладкая.

Р а з ме ры голотипа, мм: Д-0,78; В - 0,45 (соотношение размеров см. рис. 2).

Опи с ан ие. Раковина маленькая, амплетная, плосковыпуклая. Спинной край прямой или незначительно выгнут у третьей лопасти, брюшной - плоскодугообразный, концы одинаково закругленные.

Створка четырехлопастная: первая - широкая низкая; вторая у́же, в верхней части расширенная; третья - широкая, с изгибающейся вперед и расширяющейся нижней частью; четвертая - узкая гребневидная, расширяющаяся в спинном направлении. Четвертая лопасть связана за широкой уплощенной боковой лопастью дугообразным гребнем. Первая борозда узкая, короткая, вторая - значительно шире первой, угловатая, с изгибающимся вперед нижним концом, третья - длинная, широкая, расширяющаяся в нижней части.

Велюм узкий, отделен от лопастей широкой, нечетко ограниченной бороздой. На переднем конце он начинается немного ниже спинного угла и протягивается почти до заднеспинного угла. В переднебрюшной части створки велюм образует слабовогнутый долон. Отчетливого диморфизма не наблюдается.

Маргинальная скульптура в виде мелких зубков. Поверхность створок гладкая.

И з ме нч и в ость. Основные признаки характеризуются постоянством. В незначительной мере варьируются степень вогнутости долона и ширина велюма, но кажется, что это объясняется незакономерной индивидуальной изменчивостью. Маргинальная скульптура и ребристость поверхности наблюдаются лишь в редких случаях и зависят от сохранности.

С р а в не н и е. Ближайшими видами $T$. neckajae оказываются $T$. zastro-

\section{ТАБЛИЦА III}

1-6. Tetrada neckajae sp. n. 1-2 - левая створка Os 3047 , вид сбоку и с брюшной части, скв. Винни, гл. 15,5 м, FraP; 3-4 - правая створка Os 3035 сбоку и с брюшного края, скв. Винни, гл. 15,5 м, $\mathrm{F}_{\mathrm{I}} \mathrm{P} ; 5-6$ - голотип, правая створка Os 3037 сбоку и с брюшного края, скв. Винни, гл. 15,5 м, F 1 гP.

7-10. Tetrada variabilis sp. n. 7 - голотип, левая створка Os 3067, вид сбоку, скв. Берзини, гл. 434,9 м, $\mathrm{F}_{\mathrm{Ia}}$; 8-9 - правая створка Os 3066 , вид сбоку и со спинной части, скв. Берзини, гл. 434,9 м, $\mathrm{F}_{\mathrm{I}}$; 10 - правая створка Os 3065 , вид сбоку, скв. Ярва-Мадизе, гл. 95,1 м, Е.

Изображения $1-2,8-9$ получены на СЭМ. Увеличения: $1-\times 105 ; 2-\times 101$; $3,5-\times 57 ; 4,6-\times 50 ; 7,10-\times 61 ; 8-\times 99 ; 9-\times 66$.

\section{ТАБЛИЦА IV}

1-7. Primitiella ? insolens sp. n. $-1-2$ - голотип, левая створка Os 3015 , вид сбоку и с брюшного края, скв. Винни, гл. 21,4 м, $\mathrm{F}_{\mathrm{I}} \mathrm{PP} ; 3-4-$ левая створка Os 3016, вид сбоку и скульптура боковой поверхности, скв. Винни, гл. 21,4 м, FIaP; 5-6 - правая створка Os 3012 с внешней и внутренней стороны, Моонакюла, Е’Р; 7 - левая створка Os 3013 , внд сбоку, скв. Винни, гл. 21,4 м, F ${ }_{\mathrm{IaP}}$.

8-12. Pyxion rakverensis sp. n. 8-10 - голотип, раковина Os 3041 с правой и левой стороны и с брюшного края; Пийлсе, E'P; 11 - раковина Os 3040 со спинного края, скв. Винни, гл. 38,5 м, Е'P; 12 - раковина Os 3048 со стороны левой створки, скв. Ваянгу, гл. 125,5 м, Е.

Изображения $3-4,12$ получены на СэМ. Увеличения: $1-2,5-7-\times 68 ; 3-$ $\times 84 ; 4-\times 282 ; 8-11-\times 61 ; 12-\times 95$. 
wensis Schallreuter, 1969, отличающийся более угловатым очертанием и иной формой борозд (первая борозда прямая, вертикальная; вторая - короче чем у $T$. zastrowensis, угловатая; третья - с расширенным нижним концом) и $T$. krausei var. ordinata (Sarv, 1959), по сравнению с которым новый вид имеет менее выпуклые лопасти иной формы и значительно меньшие размеры. От T. excisa Sidaravičiene, 1971 новый вид отличается прежде всего более короткой раковиной и короткими передними бороздами. От остальных близких по рас-

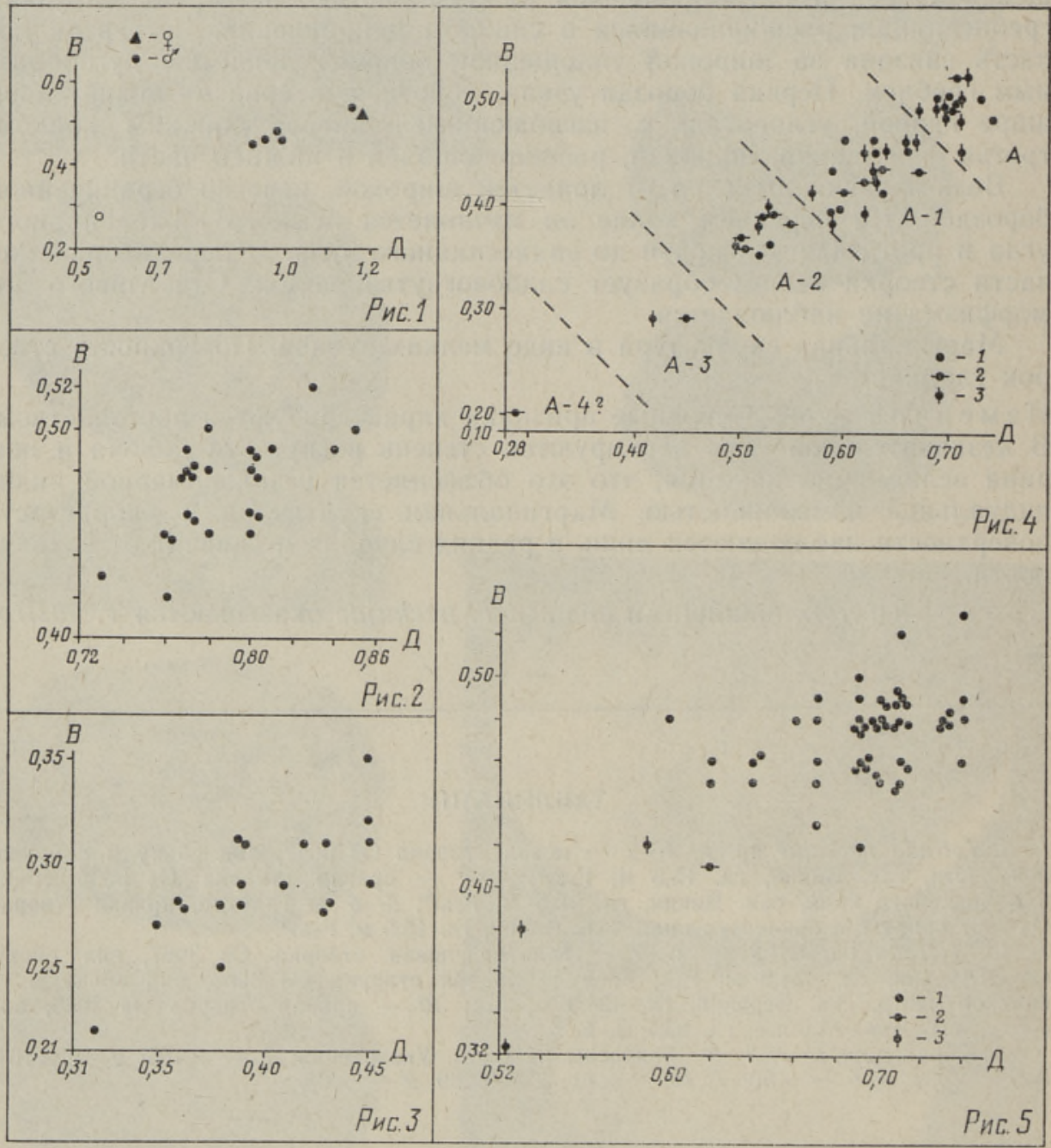

Рис. 1. Соотношение размеров Seviculina reticulata gen. n. sp. n.

Рис. 2. Соотношение размеров Tetrada neckajae sp. n. Скв. Винни, гл. 15,5 м, F Рис. 3. Соотношение размеров Hemiaechminoides minusculus sp. n.

Рис. 4. Соотношение размеров Pyxion rakverensis sp. n. 1 - Пийлсе, E’P; 2 - Рягавере, Е'Р; 3 - скв. Винни, гл. 36,2 м, Е'Р.

Рис. 5. Соотношенне размеров Primitiella ? insolens sp. п. Скв. Винни, глубина 1 21,4 м, F IaP; $_{2}-29,0$ м, E'T; $3-38,5$ м, E'P. 
пространению видов $T$. krausei (Steusloff, 1895), T. ovalis (Sarv, 1959) и $T$. ventroconcava Schallreuter, $1976 T$. nесkajae отличается прежде всего отсутствием пористости на лопастях.

Р аспространен ие. Паэкнаская пачка набалаского горизонта $\left(\mathrm{F}_{\mathrm{I}} \mathrm{aP}\right)$ в Северо-Восточной Эстонии; набалаский горизонт в Восточной Латвии (4-й комплекс по Пылма и др., 1977).

Местонахождение и м а тери ал. Скв. Винни, гл. 18,8 м1 экз., гл. 15,5 м - 39 экз.; скв. Моэ, гл. 40,8 м - 2 экз.; скв. Берзини, гл. 438,4 м -1 экз.

Tetrada variabilis sp. n.

Табл. III, фиг. 7-10

Голотип. Левая створка Os 3067 в ИГ АН ЭССР; скв. Берзини, гл. 434,9 м, набалаский горизонт.

Ди агноз. Раковина маленькая, постплетная. Первая и вторая лопасти короткие; вторая с расширенной средней частью, всегда связана с боковой лопастью. Третья и четвертая лопасти длиннее, загибающиеся вперед в нижней части. Борозда между лопастями и велюмом узкая, расширяясь только на заднем конце. Поверхность створок беспорядочно мелкопористая.

Р а з м ер ы голотипа, мм: Д $-0,97 ; \mathrm{B}-0,57$.

Описание. Раковина маленькая, постплетная, плосковыпуклая. Қонцы раковины закругленные, задний при этом более широко. Четырехлопастная скульптура створки выражена четко. Передние две лопасти короткие, их нижние концы сливаются довольно далеко от велюма. Первая лопасть дугообразная, вторая - почти вертикальная с немного расширенной средней частью, третья - длиннее, ее основание сильно расширяется в направлении переднего конца, четвертая - шире остальных, слегка дугообразна. Первая борозда относительно узкая, слегка наклоненная, кончается примерно на полувысоте створки, вторая - длиннее и шире, изменчивой формы, третья широкая, длинная, протягиваясь почти до велюма, из-за чего третья и четвертая лопасти связаны только узким гребнем.

Велюм начинается посередине переднего конца или выше. Под третьей бороздой он находится близко к свободному краю, удаляясь к концам. Велюм имеет вид угловатого гребня, который в передней и переднебрюшной части створки более тонкий, килеобразный, образует вогнутую полость у свободного края. От лопастей велюм отделен узкой, явно расширяющейся на заднем конце бороздой. Явный диморфизм не обнаружен. Маргинальная скульптура наблюдается на обеих створках под велюмом в виде ряда мелких шипиков у свободного края.

Изменчи вость. Первая и вторая борозды сильноварьирующей формы. Первая борозда кончается немного выше или ниже середины створки, она почти прямая, немного расширенная в нижней части или слегка дугообразна. Вторая борозда слабо дугообразна, кончаясь всегда ниже полувысоты створки, доходит иногда почти до борозды, окружающей лопасти. Вполне возможно, что в дальнейшем североэстонский материал придется рассматривать в качестве нового подвида с более короткими передними бороздами.

$\overline{\mathrm{Cp}}$ авнение. Новый вид является несомненно последователем T. krausei (Steusloff, 1895), но отличается от последнего мелкой беспорядочной пористостью створок, более равномерной шириной лопастей, всегда соединенными второй и боковой лопастями, менее загибающимся вперед нижним концом второй борозды, маргинальной скульптурой. 
Р аспространение. Раквереский (E) и набалаский $\left(\mathrm{F}_{\mathrm{I}} \mathrm{a}\right)$ горизонты Северной Эстонии; набалаский $\left(\mathrm{F}_{\mathrm{I}} \mathrm{a}\right)$ горизонт Восточной Латвии (4-й комплекс по Пылма и др., 1977).

Местон ахождение и м а те ри ал. Скв. Винни, E'P, гл. $41,4 \mathrm{M}-$ 1 экз.; Е'Т, гл. 31,9 м -8 экз.; гл. 31,65 м -1 экз.; гл. 29,0 м 4 экз.; гл. 27,2 м - 2 экз.; скв. Ярва-Мадизе, Е'Р, гл. 102,0 м - 1 экз.; Е'Т, гл. 95,1 м - 2 экз.; скв. Ваянгу, Е, гл. 123,4 м - 1 экз.; гл. 114,4 м - 1 экз.; скв. Қилтси, $\mathrm{F}_{\mathrm{I}} \mathrm{T}$, гл. 111,9 м -1 экз.; скв. Берзини, $\mathrm{F}_{\mathrm{I}}$, гл. 434,9 м - свыше 100 экз.; гл. 437,7 м -6 экз.; гл. 438,1 м -2 экз.; гл. 438,8 м -11 экз.

\section{Семейство Circuliniidae Neckaja, 1966 \\ Род Рухіon Thorslund, 1948 \\ Pyxion rakverensis sp. $\mathrm{n}$. \\ Табл. IV, фиг. 8-12}

Голотип. Раковина Os 3041 в ИГ АН ЭССР; Пийлсе, раквереский горизонт, пийлсеская пачка.

Ди агноз. Раковина маленькая, слабо преплетная, выпуклая, с эпиклинной спиной. В среднеспинной части створки развита неглубокая борозда, перед ней округлый бугор. Широкая краевая лопасть отделена от боковой поверхности неглубокой ложбинкой. Поверхность гладкая.

Р а з меры голотипа, мм: Д $-0,76$; В $-0,49$ (соотношение размеров см. рис. 4).

О п и са н ие. Раковина маленькая, слабо преплетная, выпуклая, почти равностворчатая. Замочный край прямой, спина эпиклинная. Спинные углы тупые, нечеткие, передний немного больше заднего. Концы и брюшной край дугообразны. Наибольшая длина - посередине створки.

В среднеспинной части створки наблюдается неглубокая борозда, суживающаяся в средней и сильно расширяющаяся в нижней, слегка вперед отогнутой части. В нижней расширенной части борозды, посередине створки, развит довольно большой, округлый бугровидный отпечаток аддукториального мускуля. Перед бороздой расположен довольно высокий округлый бугор, где наблюдается наибольшая ширина раковины. Сзади бугор ограничивается бороздой, его верхняя и передняя части нечетко ограничены.

На спинном крае развиты высокие спинные выступы. Они короче замочного края, их наибольшая высота ближе к заднему концу. Между ними образуется более или менее широкая спинная поверхность.

Параллельно свободному краю расположена невысокая краевая лопасть, которая отделена от боковой поверхности узкой неглубокой ложбинкой. В брюшной (особенно в переднебрюшной) части створки лопасть широкая, занимает примерно $1 / 3$ высоты створки, на концах суживается, простирается до спинных углов. От смычного края лопасть отделена невысоким гребнем (= Pseudovelum : Schallreuter, 1968, c. 250), более четким на брюшном крае, менее - на концах. Этот гребень чаще на брюшном, реже на заднем крае выступает над смычным краем. Между гребнем и смычным краем образуется широкая краевая поверхность.

Маргинальная скульптура левой створки в виде ребра, рядом с которой правая створка незначительно охватывает левую. Поверхность створок гладкая.

Изменчи вость. Во всех возрастных стадиях имеются экземпляры со слаборазвитой скульптурой. Личиночные стадии отличаются от 
взрослых большей выпуклостью и более широкой спинной поверхностью.

C р а внени е. Pyxion rakverensis sp. п. напоминает по общему расчленению створок $P$. nitidum Sarv, 1963, но отличается от последнего меньшей выпуклостью боковой поверхности и краевой лопасти и слаборазвитыми бороздами; от $P$. keilaensis Sarv, 1959 отличается прежде всего гладкой поверхностью.

Р аспространение. Раквереский горизонт, пийлсеская пачка (E'P).

Местонахождение и м а тери ал. Рягавере -28 экз.; Пийлсе - 35 экз.; Моонакюла - 8 экз.; скв. Винни, гл. $33,4-40,0$ м 90 экз.

Семейство Monotiopleuridae Guber et Jaanusson, 1964

Род Primitiella Ulrich, 1894

Primitiella? insolens sp. $\mathrm{n}$.

Табл. IV, фиг. $1-7$

Голоти п. Левая створка Os 3015 в ИГ АН ЭССР; скв. Винни, гл. 21,4 м, набалаский горизонт, паэкнаская пачка.

Ди агно 3. Раковина маленькая, постплетная, плосковыпуклая. Наибольшая длина раковины - посередине створки. Мускульный отпечаток в виде округлого гладкого бугра помещается ближе к переднему концу; остальная боковая поверхность грубосетчатая.

Р а з м ер солотипа, мм: Д-0,69; В - 0,50 (соотношение размеров см. рис. 5).

Описание. Раковина маленькая, постплетная, плосковыпуклая. Наибольшая длина раковины - посередине створки. Замочный край прямой, длинный, но короче общей длины раковины. Спина эпиклинная, спинной край плоскодугообразный. Спинные углы тупые, передний немного больше заднего. Концы закругленные, брюшной край слегка выгнут, наклонен к заднему концу. На брюшном крае боковой поверхности имеется небольшое вздутие, выступающее над смычным краем.

Выше середины створки, немного ближе к переднему концу размещается небольшой округлый серединный бугор, в таком же виде он наблюдается и на внутренней поверхности створки (табл. IV, фиг. $5-6)$.

Боковая поверхность, кроме серединного бугра и нечетко ограниченной спинной поверхности, грубосетчатая.

Из менчи вость. Немногочисленные экземпляры из раквереского горизонта отличаются от более молодых меньшими размерами. Наблюдается колебание длины раковины.

C р а внен ие. Вид включен в род Primitiella условно, так как отличается от остальных представителей рода отсутствием серединной борозды и диморфизма. Соотношение створок не установлено; материал представлен только отдельными створками.

От представителей рода Tsitrella Sarv, 1959 представители нового рода отличаются отсутствием серединной борозды и четко ограниченной нескульптурированной краевой поверхности.

3 а меч а н я. Вид включен в род Primitiella на основании характерного очертания и отсутствия прикраевых структур.

Р аспростр анение. Раквереский горизонт (Е) и паэкнаская пачка набалаского горизонта (FIaP) Әстонии. 
Местонахождение иі матери ал. Паэкна, FIaP - 1 экз.; Моонакюла, Е'Р - 4 экз.; Пийлсе, Е'Р - 1 экз.; скв. Винни, Е'Р, 38,5 м 3 экз.; Е’Т, гл. 29,0 м - 1 экз.; FІаР, гл. 21,4 м - 62 экз.; скв. Моэ, $\mathrm{F}_{\mathrm{I}} \mathrm{PP}$, гл. 52,0 м -2 экз.

Семейство Jaanussoniidae Schallreuter, 1971

Род Hemiaechminoides Morris et Hill, 1952

Hemiaechminoides minusculus sp. $\mathrm{n}$.

Табл. II, фиг. 4-8

Голотип. Раковина Os 3001 в ИГ АН ЭССР; скв. Ваянгу, гл. 125,5 м, раквереский горизонт.

Ди а гноз. Раковина маленькая, овальная, неравностворчатая. Правая створка охватывает левую на свободном крае. Левая створка выступает над правой на спинном крае, посередине выступа развит тупой шип. Поверхность гладкая.

Р а з меры голотипа, мм: Д - 0,42 ; В $-0,29$ (соотношение размеров см. рис. 3 ).

Оп и с н и е. Раковина маленькая, овальная, неравностворчатая, амплетная, умеренно выпуклая. Замочный край прямой, спинные углы очень тупые, равные, нечеткие. Концы одинаково закругленные, брюшной край дугообразный, иногда с нечеткой выгнутостью в средней части. Правая створка с небольшим выступанием охватывает левую по всему свободному краю; охват глубже на брюшном крае. Спинной край правой створки почти совпадает с замочным краем. У левой створки на спинном крае развит невысокий спинной выступ, посередине которого расположен тупой или в разной мере заостренный короткий шип. Поверхность створок гладкая.

Из менчи вость. Наблюдаются небольшие изменения в очертании раковин.

С равнение. H. minusculus sp. п. очень близок к $H$. avus Schallreuter, 1971, но отличается от последнего более вытянутой раковиной и коротким шипом на спинном крае, который направлен в сторону. От H. rossica Neckaja, 1966 новый вид отличается меньшими размерами и расположением шипа посередине спинного края.

$\mathrm{P} \mathrm{a} \mathrm{cп} \mathrm{р} \mathrm{ост} \mathrm{ран} \mathrm{ение.} \mathrm{Раквереский} \mathrm{горизонт} \mathrm{(Е)} \mathrm{и} \mathrm{паэкнаская} \mathrm{пачка}$ набалаского горизонта $\left(\mathrm{F}_{\mathrm{I}} \mathrm{PP}\right)$ в Эстонии.

Местон ахождение и м а тер и ал. Скв. Ваянгу, Е, гл. 125,5 м8 экз.; скв. Винни, Е'Р, гл. $33,4-38,5$ м - 5 экз.; Е'Т, гл. 31,9 м 1 экз.; FІаР, гл. $24,6-25,5$ м -6 экз.

\section{ЛИТЕРАТ У РА}

Пылма Л., Сарв Л., Хинтс Л. Расчленение ордовикских отложений разреза скв. Берзини (Юго-Восточная Латвия). - Изв. АН ЭССР. Хим. Геол., 1977, 26, № 2, $113-121$.

Schallreuter, $R$. Drepanellacea (Ostracoda, Beyrichiida) aus mittelordovizischem Backsteinkalkgeschiebe II. Laterophores lateris g. n. sp. n., Pseudulrichia bucera und Pedomphalella egregia (Neckaja). - Ber. deutsch. Ges. geol. Wiss., A, Geol. Paläont., 1968, 13, N 2, 247-261. 


\section{UUED OSTRAKOODID BALTIKUMI ORDOVIITSIUMIST}

On kirjeldatud uut perekonda ja 6 uut liiki ostrakoode rakvere ja nabala lademest ning esitatud andmed nende liikide levikust Põhja-Eesti läbilőigetes ja ühes Ida-Läti puuraugus.

\section{T. MEIDLA}

\section{NEUE OSTRAKODEN AUS DEM ORDOVIZIUM DES BALTIKUMS}

Im vorliegenden Artikel beschreibt man eine neue Gattung und 6 neue Arten aus der Rakvere- und Nabala-Stufe Estlands und Ostlettlands. Ihre Diagnosen:

Seviculina gen. n.: präplet, unisulcat, Sulcus kurz und bogenförmig, Präadduktorialnodus schwach oder fehlend. Velum bei den tecnomorphen Klappen als mehr oder weniger deutlicher Kiel, der sich posteroventral von dem freien Rand allmählich entfernt und am Ende einen Dorn tragen kann. Bei den heteromorphen Klappen vereinen sich Velum und Histium anteroventral. Marginalskulptur bei den linken Klappen als radialgestreifter Flansch oder Rippe. Oberfläche retikuliert oder poriert.

Seviculina reticulata gen. n. sp. n.: Seviculina mit länglicher Gestalt. Velum bei den tecnomorphen und Histium bei den heteromorphen Klappen bogenförmig, verlaufen bis zum posterozentralen Teil der Klappe. Velum bei den tecnomorphen Klappen am Ende bedornt. Oberfläche retikuliert.

Tetrada neckajae sp. n.: klein, amplet. Der vierte Lobus durch eine Rippe mit dem Ventrallobus verbunden. Die ersten Sulci kurz, dabei der zweite breiter, eckig. Sulcus zwischen den Loben und dem Velum breit, undeutlich. Oberfläche glatt.

Tetrada variabilis sp. n.: klein, postplet. Der erste und zweite Lobus kurz, der zweite breiter in der Mitte, stets mit dem Ventrallobus verbunden. Der dritte und vierte Lobus sind länger, biegen sich ventral in anteroventraler Richtung. Der erste Sulcus kurz, der zweite variabel, der dritte lang und breit. Sulcus zwischen den Loben und dem Velum schmal, verbreitert sich nur am Hinterende. Lateraloberfläche chaotisch poriert.

Py.xion rakverensis sp. n.: klein, präplet, stark konvex, mit dem kleinen Präadduktorialnodus und dem kurzen, flachen Sulcus als Graben am dorsozentralen Teil der Klappe. Dorsum epicline, der breite Ventrallobus von der Lateraloberfläche durch den flachen Sulcus getrennt. Oberfläche glatt.

Primitiella ? insolens sp. n.: klein, postplet, schwach konvex. Muskelfleck anterozentral als rundlicher Tuberkel (auch in der Innenansicht), glatt; übrige Oberfläche retikuliert. Hemiaechminoides minusculus sp. n.: klein, amplet, oval. Die rechte Klappe hüllt die linke den freien Rand entlang. Die linke Klappe dorsal mit dem Umbo, das zentrodorsal als Stachel entwickelt ist und in laterodorsale Richtung zeigt. Oberfläche glatt. 